\title{
Feasibility Study of Hybrid Corn and Sweet Corn Farm in Plemahan District, Kediri Regency
}

\author{
Pujastuti Sulistyaning Dyah ${ }^{1, *}$, Nur Kahfi ${ }^{1}$ \\ ${ }^{1}$ Department of Agribusiness, Universitas Muhammadiyah Yogyakarta, Yogyakarta
}

\begin{abstract}
This study aims to determine the cost, revenue, farmers' income, profitability and feasibility of sweet corn and hybrid corn farming in the Plemahan district. The technique of determining the research area is done by Purposive Sampling with the consideration that the Plemahan district has the highest corn production. Determination of respondent samples was done by census of 20 sweet corn farmers and 30 hybrid corn farmers. The method of analysis is carried out by describing the results of tabulations including income, $\mathrm{R} / \mathrm{C}$, capital productivity, land productivity, and labor productivity. The results showed that total farming costs were IDR 8,438,496 for sweet corn and IDR 9,473,266, - for hybrid corn with a land area of $4000 \mathrm{~m}$ Farmers' lncome of sweet corn farming is IDR $7,915,054$ during one planting season (3 months) of hybrid corn of IDR $7,611.52$, - during one planting season (4 months) The profit obtained from sweet corn is IDR 4,473,588 while the profits of hybrid corn farmers amounted to IDR $3,639,734$. The feasibility of sweet corn is higher than hybrid corn.
\end{abstract}

\section{Introduction}

Fulfillment of world food needs is met by an agrarian country. Indonesia as an agrarian country with several subsectors, namely livestock subsector, fisheries subsector, forestry subsector, food crop subsector, and horticulture sub-sector. The food crop sub-sector plays a big role for most of the farming communities that make up the majority of the population in Indonesia. This subsector has a role in national food security. Among food crops that are the mainstay of farmers' livelihoods are seasonal crops.

Seasonal plants include rice, beans, tubers, pulses, and vegetables. One type of crop that is needed is corn. The economic value of corn improves along with the development of the agricultural industry sector. Corn is needed because it is used to food consumption and also the growing development of the animal feed industry. Some types of corn cultivated by farmers include hybrid corn and sweet corn. Sweet corn is more likely to be consumed as food than for the feed industry.

According to [1], states that corn production in Kediri Regency has several sub-districts that have potential in the food crop sub-sector, especially maize, which produces

\footnotetext{
* Corresponding author: pujastuti@umy.ac.id
} 
sufficiently high corn production with a stable increase from 2014-2016. While the highest corn production is Plemahan Subdistrict which produces 287,094-327,788 Kw in 20142016.

There are two maize cropping patterns in Plemahan District. The first pattern is: ricesweet corn and hybrid corn and the second cropping pattern is: rice- hybrid corn-hybrid corn. Both are planted in fields after rice. In the second planting season, some farmers grow sweet corn and others grow hybrid corn. The number of farmers who grow sweet corn is not as much as farmers who grow hybrid corn, because indeed the type of sweet corn is only known in recent years but is popular with the community because of its sweet taste. Planting sweet corn is 3 months, shorter than hybrid corn which is 4 months. The results of the research by [2], show that the planting period for sweet corn is only 2 months and hybrid maize is in 3 months. There are several differences in the use of inputs and results of both types of that corn. Which problems are more profitable, by knowing how much the costs, income, profits, and feasibility of the two farms?

\section{Methodology}

This research method uses descriptive analysis method. The descriptive method is a method for collecting, studying problems, and then solving them using analysis [3]. Location sampling is done by purposive sampling, namely Puhjarak Village, Plemahan District, Kediri Regency. Determination of respondent samples was done by census of 20 sweet corn farmers and 30 hybrid corn farmers. The technique of primary data collection was carried out from farmer information with interview techniques using a questionnaire. While secondary data is obtained from relevant agencies, namely BPS, sub-districts, villages, and the local Food Crops Agriculture Service.

The method of analysis is carried out by describing the results of tabulations, there are: $\mathrm{R} / \mathrm{C}$, capital productivity, land productivity, and labor productivity. The $\mathrm{R} / \mathrm{C}$ is comparison between revenues and total costs. Capital productivity is the comparison between the net return that has been reduced by the implicit costs other than own capital, with the total cost. Land productivity is net return less any implicit costs other than rent on the land itself. Labour Produktivity is comparison between the net returns minus any implicit costs other than labor costs themselves, to the total number of days worked for people. The number of samples of maize farmers as respondents was 50 farmers.

\section{Literature Review}

Corn has an important role as the main ingredient in the food and animal feed industry. The demand for corn continues to increase in line with population growth as a result of the increased need for food and consumption of animal protein [4].

According [5], in order to increase the productivity of maize, the spread of corn technology innovation using hybrid varieties has been developed. The research conducted by [6], with the title "Comparison of Sweet Corn and Ordinary Corn Farming in Tontalete Village Tema District, Minahasa Utara District" shows that in one year there are three growing seasons. The costs incurred for ordinary maize farming are IDR 32,121,200, while the costs incurred for sweet corn farming were IDR 17,982,500. The income obtained from sweet corn farming is greater than sweet corn farming in one year. Sweet corn farming income per hectare is IDR 21,180,320. Meanwhile, regular maize only earns an income per hectare of IDR 7,266,300 per year. Ordinary corn income only reaches 30 percent of the income of sweet corn during one year of planting. 
The related study conducted by [7], entitled "Production Analysis and Comparative Inter-Farming with Nonhibrida Hybrid Maize in Palolo District, Sigi Regency", showed that costs incurred for 4 months (1 season) per hectare of hybrid corn farming were greater than non hybrid corn. Hybrid corn farming costs IDR 3,999,381.71 and corn nohibrida IDR $2,846,125.65$. Income for hybrid corn farming is higher, which is IDR 4,882,225.79 and nonhibrida corn for IDR 2,691,452.10, hybrid R/C of 2.22 and nonhibrida 1.95. This shows that hybrid corn farming is more efficient than nonhibrida.

\section{Result And Discussion}

The cost of corn farming includes the cost of production facilities (consisting of seeds, fertilizers, pesticides, and land), labor costs, equipment costs, and other costs. Labor costs consist of the amount of outside work and labor in the family. Likewise the cost of arable land, own land is calculated as implicit costs as well as labor costs in the family and own capital interest. The seed cost component as shown in Table 1.

Tabel 1. Cost of Using Seeds in Farming of Sweet Corn and Hybrid Corn on $4000 \mathrm{~m} 2$ land in Plemahan District

\begin{tabular}{|l|r|r|}
\hline Description of Seed Use & Sweet Corn & Hibrid Corn \\
\hline Seed (KG) & 4.12 & $11 ., 42$ \\
\hline Price (IDR) & 280,000 & 75,000 \\
\hline Cost & $\mathbf{1 , 1 5 3 , 6 0 0}$ & $\mathbf{8 5 , 5 0 0}$ \\
\hline
\end{tabular}

The cost of sweet corn seeds is higher than hybrid corn. The price of sweet corn seeds is cheaper, but the needs are more than hybrid corn. The fertilizer cost component as shown in Table 2 .

Table 2. Costs for Using Fertilizers in Farming of Sweet Corn and Hybrid Corn on $4000 \mathrm{~m} 2$ land in Plemahan District

\begin{tabular}{|l|r|r|r|r|}
\hline \multirow{2}{*}{$\begin{array}{l}\text { Description of Seed } \\
\text { Use }\end{array}$} & \multicolumn{2}{|c|}{ Sweet Corn } & \multicolumn{2}{|c|}{ Hibrid Corn } \\
\cline { 2 - 5 } & Total (Kg) & Cost (IDR) & Total (Kg) & Cost (IDR) \\
\hline Urea & 141.50 & 254,698 & 129.24 & 232,629 \\
\hline $\mathrm{Za}$ & 102.26 & 143,168 & 129.24 & 180,933 \\
\hline Phonska & 76.30 & 175,499 & 80.29 & 184,657 \\
\hline Pupuk kandang & 871.35 & 435.677 & 846.71 & 422,857 \\
\hline Total & & $\mathbf{1 , 0 0 9 , 0 4 2}$ & & $\mathbf{1 , 0 2 1 , 0 7 6}$ \\
\hline
\end{tabular}

Table 3. Cost of Using Pesticides in Farming Sweet Corn and Hybrid Corn on $4000 \mathrm{~m} 2$ Land in Lemahan District

\begin{tabular}{|l|r|r|r|r|}
\hline \multirow{2}{*}{$\begin{array}{l}\text { Description of Seed } \\
\text { Use }\end{array}$} & \multicolumn{2}{|c|}{ Sweet Corn } & \multicolumn{2}{c|}{ Hibrid Corn } \\
\cline { 2 - 5 } & Total & Cost (IDR) & Total & Corn(IDR) \\
\hline Cabrio (L) & 1,45 & 217.241 & 1,66 & 249.429 \\
\hline Buldok buyer (L) & 1,46 & 77.515 & 1,81 & 95.703 \\
\hline Insure max (L) & 2,08 & 74.869 & 1,75 & 63.086 \\
\hline Kayabas (L) & 0,54 & 12.890 & 1,28 & 30.606 \\
\hline Regent (L) & 1,45 & 174.478 & 1,66 & 199.543 \\
\hline Furadan (Kg) & 5,01 & 80.194 & 5 & 87.589 \\
\hline Antracol(Gram) & 1,8 & 32.111 & 2 & 29.100 \\
\hline Admit(Gram) & 3,2 & 38.298 & 3,9 & 34.720 \\
\hline Total & & $\mathbf{7 0 7 . 5 9 6}$ & & $\mathbf{7 8 9 . 7 7 6}$ \\
\hline
\end{tabular}


The total cost of fertilizer is relatively the same between sweet corn and hybrid corn. The components of the cost of pesticides as shown in Table 3.

As for fertilizer costs, the total cost of pesticides is also not very different between sweet corn and hybrid corn. Out-of-family labor costs for sweet corn farmers and hybrid corn in Plemahan district are listed in Table 4.

Tabel 4. Cost of Out-of-Family Labor in Sweet Corn and Hybrid Corn Farming for One Planting Season on $4000 \mathrm{~m} 2$ Land.

\begin{tabular}{|l|r|r|}
\hline \multirow{2}{*}{ Labor Description } & Sweet Corn & Hibrid Corn \\
\cline { 2 - 3 } & Cost (IDR) & Cost (IDR) \\
\hline Machine Land Processing & 102,171 & 342,629 \\
\hline Human Land Processing & 17,030 & 47,238 \\
\hline Planting & 229,955 & 206,914 \\
\hline HPT Control & 22,971 & 33,562 \\
\hline Weeding & 13,886 & 32,229 \\
\hline Fertilization & 132,034 & 163,714 \\
\hline Harvest & 238,630 & 605,143 \\
\hline Total & $\mathbf{7 5 6 , 6 7 7}$ & $\mathbf{1 , 4 3 1 , 4 2 9}$ \\
\hline
\end{tabular}

The amount of labor costs in the family the hybrid corn family is higher than sweet corn. The biggest difference is the cost of harvest, because the amount of hybrid corn production is higher than sweet corn. The cost of equipment in corn farming that is taken into account is the cost of depreciating the equipment. Depreciation costs for equipment in corn are listed in Table 5.

Table 5. Costs for Depreciating Agricultural Equipment in Sweet Corn Farmers and Hybrid Corn in Plemahan District during One Planting Season

\begin{tabular}{|l|r|r|}
\hline \multirow{2}{*}{ Kinds of Tools } & Sweet Corn & Hibrid Corn \\
\cline { 2 - 3 } & Cost (IDR) & Cost (IDR) \\
\hline Hoe & 7,722 & 4,343 \\
\hline Sickle & 5,657 & 6,582 \\
\hline Handsprayer Manual & 11,765 & 14,113 \\
\hline Scoop & 1,242 & 1,962 \\
\hline Bucket & 3,975 & 6,083 \\
\hline Sharp Stick & 1,169 & 1,782 \\
\hline Total & $\mathbf{3 1 , 5 3 0}$ & $\mathbf{3 4 , 8 6 5}$ \\
\hline
\end{tabular}

The amount of equipment depreciation in sweet corn and hybrid corn is not much different. Other costs for corn farming are costs incurred other than production facilities, seed costs, fertilizer costs, outside family labor costs and depreciation costs. Other costs in this case are land tax, fuel, group fees, corn mill costs, and transportation costs. The total other costs are listed in Table 6.

Table 6. Other Costs for Sweet Corn Farmers and Hybrid Corn in Plemahan District during One Planting Season

\begin{tabular}{|l|r|r|}
\hline \multirow{2}{*}{ Additional Cost } & Sweet Corn & Hibrid Corn \\
\cline { 2 - 3 } & Cost (IDR) & Cost (IDR) \\
\hline Land Tax Costs & 12,722 & 11,204 \\
\hline Fuel Costs & 39,025 & 22,833 \\
\hline Group Fee Costs & 36,250 & 40,116 \\
\hline Turnover Costs & 0 & 140,948 \\
\hline Transportation & 30,000 & 138,000 \\
\hline Total & $\mathbf{1 1 7 , 9 9 7}$ & $\mathbf{3 5 3 , 1 0 1}$ \\
\hline
\end{tabular}


The amount of other costs in hybrid corn is higher than sweet corn, with a difference of IDR 235,101. There is a cost of milling in hybrid corn, whereas in sweet corn it does not need to be milled because it is sold in the form of hump corn and most of it is sold at the harvest location. Hybrid corn is more abundant than sweet corn and all of them are transported to the house to be dried in the sun before being ground.

Explicit total costs are costs that are actually incurred by farmers in one production process. The explicit cost of corn farming during one planting season consists of production facilities, out-of-family labor, depreciation of equipment and other costs. Table 7 below is the explicit total cost of sweet corn farmers and hybrid corn in Plemahan district during one planting season.

Table 7. Explicit Costs of Sweet Corn Farmers and Hybrid Corn in Plemahan District for One 4,000 $\mathrm{m}^{2}$ Planting Season

\begin{tabular}{|l|r|r|}
\hline \multirow{2}{*}{ Type of Explicit Cost } & Sweet Corn & Hibrid Corn \\
\cline { 2 - 3 } & Cost (IDR) & Cost (IDR) \\
\hline Seed & $1,153,600$ & 856,500 \\
\hline Fertilizer & $1,009,042$ & $1,021,076$ \\
\hline Pesticide & 707,596 & 789,776 \\
\hline TKLK & 756,677 & $1,431,429$ \\
\hline Land Rent & $1,220,625$ & 934,138 \\
\hline Tool depreciation & 31,530 & 34,865 \\
\hline Biaya Lain-lain & 117,997 & 353,101 \\
\hline Total & $\mathbf{4 , 9 9 7 , 0 6 7}$ & $\mathbf{5 , 4 2 0 , 8 8 5}$ \\
\hline
\end{tabular}

The biggest use and difference in out-of-family labor (TKLK). Apart from using paid out-of-family labor, this corn farmer also uses labor in the family (TKDK). The number of TKDK used by farmers is shown in Table 8.

Table 8. Labor Costs in the Family for Sweet Corn and Hybrid Corn Farming for One Planting Season on $4000 \mathrm{~m} 2$ land

\begin{tabular}{|l|r|r|r|r|}
\hline \multirow{2}{*}{ Worker Description } & \multicolumn{2}{|c|}{ Swet Corn } & \multicolumn{2}{c|}{ Hibrid Corn } \\
\cline { 2 - 5 } & Total (HKO) & Cost (IDR) & \multicolumn{1}{c|}{ Total (HKO) } & \multicolumn{1}{c|}{ Cost (IDR) } \\
\hline Seed Preparation & 0.35 & 10,616 & 0.18 & 5,514 \\
\hline Human Land Processing & 1.24 & 74,428 & 0.43 & 25,714 \\
\hline Stitching & 0 & 0 & 0.85 & 51,200 \\
\hline HPT Control & 1.99 & 119,496 & 1.82 & 109,000 \\
\hline Weeding & 1.43 & 85,676 & 1.56 & 93,857 \\
\hline Fertilization & 3.98 & 238,934 & 4.93 & 295,714 \\
\hline Irrigation & 1.42 & 84,934 & 2.21 & 132,343 \\
\hline Drying & 0 & 0 & 7.87 & 472,071 \\
\hline Total & $\mathbf{1 0 . 4 1}$ & $\mathbf{6 1 4 , 0 8 4}$ & $\mathbf{1 9 . 8 5}$ & $\mathbf{1 , 5 8 5 , 4 1 3}$ \\
\hline
\end{tabular}

Workers in the family on hybrid corn farming are higher than sweet corn. The difference in costs is IDR 971,329, -. The biggest difference is in the cost of drying.

The cost of own capital is calculated as an implicit cost even though the capital used is equity, which takes into account bank interest of $12 \%$ per year. Likewise with land owned by them calculated as an implicit cost equal to the value of local land rent. The amount of total implicit costs on corn farming is shown in Table 9. 
Table 9. Implicit Costs in Sweet Corn Farmers and Hybrid Corn in Plemahan District during One Planting Season

\begin{tabular}{|l|r|r|}
\hline \multirow{2}{*}{ Type of Implicit Cost } & Sweet Corn & Hibrid Corn \\
\cline { 2 - 3 } & Cost (IDR) & Cost (IDR) \\
\hline Own Interest Modal & 149,912 & 220,059 \\
\hline Own Land Rent Cost & $2,677,500$ & $2,166,316$ \\
\hline TKDK & 614,084 & $1,585,413$ \\
\hline Total & $\mathbf{3 , 4 4 1 , 4 9 6}$ & $\mathbf{3 , 9 7 1 , 7 8 8}$ \\
\hline
\end{tabular}

The amount of implicit costs for hybrid corn farming is greater than sweet corn, with a difference of IDR 530,292, -.

Total farming costs are the sum of the total explicit costs and implicit total costs. The total cost of corn farming is listed in Table. 10

Table 10. The Total Explicit and Implicit Total Costs for Sweet Corn Farmers and Hybrid Corn in the Plemahan District during One Planting Season

\begin{tabular}{|l|r|r|}
\hline \multirow{2}{*}{ Cost Description } & Sweet Corn & Hibrid Corn \\
\cline { 2 - 3 } & Corn (IDR) & Corn (IDR) \\
\hline Explicit Cost (IDR) & $4,997,066$ & $5,501,478$ \\
\hline Implicit Cost (IDR) & $3,441,496$ & $3,971,788$ \\
\hline Total Cost & $\mathbf{8 , 4 3 8 , 5 6 2}$ & $\mathbf{9 , 4 7 3 , 2 6 6}$ \\
\hline
\end{tabular}

The total cost of hybrid corn farming is higher than sweet corn, the difference in costs is IDR $1,034,704,-$. Revenue is the multiplication of production products at prices. Hybrid corn products in the form of shelled corn (mill) while the form of sweet corn products in the form of corn lump. The price of hybrid corn is slightly higher than the price of sweet corn. The amount of corn acceptance is shown in Table 11.

Table 11. Reception of Sweet Corn and Hybrid Corn Farming in Plemahan District for One Planting Season with an area of $4000 \mathrm{~m} 2$

\begin{tabular}{|l|r|r|}
\hline Description & Sweet Corn & Hibrid Corn \\
\hline Price (IDR) & 2,918 & 4,500 \\
\hline Total $(\mathrm{Kg})$ & 4,425 & 2,914 \\
\hline Total Revenue & $\mathbf{1 2 , 9 1 2 , 1 5 0}$ & $\mathbf{1 3 , 1 1 3 , 0 0 0}$ \\
\hline
\end{tabular}

The receipt of hybrid corn is greater than sweet corn, but only the difference of IDR 200,000 , - while the total cost of sweet corn is smaller than hybrid corn.

Farmers' Income is the difference in total revenues with explicit total costs. Table. 12 This shows the amount of income from farming sweet corn and hybrid corn.

Table 12. Farmers' income for Sweet Corn and Hybrid Corn Farming in Plemahan District for One Planting Season with an area of $4000 \mathrm{~m} 2$

\begin{tabular}{|l|r|r|}
\hline Description & Sweet Corn & Hibrid Corn \\
\hline Total revenue (IDR) & $12,912,150$ & $13,113,000$ \\
\hline Total Explicit Cost (IDR) & $4,997,066$ & $5,501,478$ \\
\hline Farmers' income & $\mathbf{7 , 9 1 5 , 0 8 4}$ & $\mathbf{7 , 6 1 1 , 5 2 2}$ \\
\hline
\end{tabular}

Even though with a smaller cost, it turns out sweet corn can provide a greater farmers' income than hybrid corn, even with a difference of IDR 303,562, -. This means that sweet corn farming produces more efficient results than hybrid corn. In contrast to the research results of [2], it shows that the average income per hectare of hybrid maize farming is IDR $1,433,855$ /season/hectare. Meanwhile, the total income obtained by farmers from sweet corn farming is IDR 3,018,147/season/hectare. Likewise with the results of research by [5], 
in Muna, Southeast Sulawesi, the income value of hybrid maize was IDR 8,596,000, while the value of local maize income was IDR 4,666,000.

Profit is the difference in total revenues with explicit total costs and implicit total costs, or the difference in farmers' income with implicit costs. (Table 13).

Table 13. Advantages of Farming Sweet Corn and Hybrid Corn in Plemahan District for One Planting Season with an area of $4000 \mathrm{~m} 2$

\begin{tabular}{|l|r|r|}
\hline Description & Sweet Corn & Hibrid Corn \\
\hline Farmers' Income (IDR) & $7,915,084$ & $7,611,522$ \\
\hline Total Implicit Cost (IDR) & $3,441,496$ & $3,971,788$ \\
\hline Profit & $\mathbf{4 , 4 7 3 , 5 8 8}$ & $\mathbf{3 , 6 3 9 , 7 3 4}$ \\
\hline
\end{tabular}

The amount of profit for sweet corn is greater than for hybrid corn, even the difference in profits is IDR 833,854, -, greater than the difference in farmers' income, because the implicit cost of hybrid corn is greater than sweet corn.

The feasibility of farming in this study was measured by R / C, Capital Productivity, Labor Productivity, and Land Productivity. Table 14 shows the level of feasibility of farming sweet corn and hybrid corn.

Table 14. Level of Feasibility in Farming Sweet Corn and Hybrid Corn in Plemahan District for One Planting Season with an area of $4000 \mathrm{~m} 2$

\begin{tabular}{|l|r|r|}
\hline Description & Sweet Corn & Hibrid Corn \\
\hline R/C & 1.53 & 1.38 \\
\hline Capital Productivity (\%) & 92.52 & 70.43 \\
\hline Land Productivity (IDR/Ha) & 17,880 & 14,520 \\
\hline Labor Productivity (IDR/HKO) & 488,653 & 263,247 \\
\hline
\end{tabular}

The value of $\mathrm{R} / \mathrm{C}$ obtained is greater than one which means it is worth trying. The results showed that in the agribusiness partnership system, corn seeds were feasible with a Benefit Cost Ratio 1.06. Meanwhile, according to [9], hybrid maize farming is very feasible, where each uses IRD costs. 1, - can benefit from IRD. 2.54. Capital productivity that is greater than the prevailing bank interest rate is $3 \%$ for 3 months (age of sweet corn) or $4 \%$ for 4 months (age of hybrid corn). The land productivity is more than the land rent, which is IDR 2,550,000 / ha for sweet corn and IDR 7,000,000 / ha for hybrid corn for one planting season. Labor productivity is greater than the wages of workers as construction workers, that is IDR 80,000 .

All the eligibility criteria it appears that the feasibility of sweet corn is higher than hybrid corn. In terms of the time of planting season sweet corn is shorter than hybrid corn ( 3 months for sweet corn and 4 months for hybrid corn), but this sweet corn is not durable to be stored. Where as in terms of market assurance, hybrid corn is better because factory demand for hybrid corn is stronger. The feasibility of sweet corn is higher than hybrid corn.

\section{Conclusion}

1. The cost of farming sweet corn is IDR 8,438,496 while the cost of hybrid corn farming is IDR 9,473,266 with a land area of $4000 \mathrm{~m} 2$. The farmers' income of sweet corn farmers is IDR 7,915,054 during one planting season (3 months) while the farmers' income of hybrid corn farmers is as big as one planting season (4 months) IDR $7,611,522$. The profit obtained from sweet corn is IDR 4,473,588 while the profits of hybrid corn farmers amounted to IDR 3,639,734.

2. The feasibility of sweet corn is higher than hybrid corn. 


\section{Suggestion}

Farmers are better advised to cultivate sweet corn in the second planting season because their income and feasibility are higher than hybrid corn. This difference in income will be very meaningful for farmers with relatively narrow arable land.

\section{References}

1. BPS, Kabupaten Kediri Dalam Angka Kediri Regency in Figures 2017 (2017).

2. Cheisya tanaem, (2020).

3. M. M. linarwati M, fathoni A, J. Manage. 2 (2), (2016).

4. H. S. P. Rahayu, IOP Conf. Ser. Earth Environ. Sci. 484, (2020).

5. Suharno and Rusdi, ]. J. Pengkaj. Dan Pengemb. Teknol. Pertan. [Journal Assess. Dev. Agric. Technol. . 20 (1)., (2017).

6. E. Gifelem, C.N., Kaunang, R., \& Ruaew, AGRI-SOSIOEKONOMI Vol. 12 (2, 41 (2016).

7. M. Antara, 17 (1), (2010).

8. H. S. et al Rahayu, (2019).

9. Sarintang, Muslimin, and A. Faisal Suddin, IOP Conf. Ser. Earth Environ. Sci. 484, (2020). 